\title{
An English Needs Analysis of Medical Doctors in Western Japan
}

\author{
lan Willey \\ Kagawa University \\ Kimie Tanimoto \\ Kagawa University \\ Gerardine McCrohan \\ Kagawa University \\ Katsumi Nishiya \\ Kansai Medical University
}

Despite the importance of English to medical doctors (MDs), few studies have examined the English needs of MDs in EFL contexts. This paper describes an English needs analysis of MDs in western Japan, which aimed to identify how these MDs use English, which English skills were most important to their work, and what their views were on English education. Findings from a questionnaire survey of MDs at one university hospital and five nonuniversity hospitals showed that these MDs primarily used English to gather information, although they were dissatisfied with their university English education for failing to improve their speaking skills. Interviews revealed that English use in unscripted situations causes stress for these MDs, and that most of their English-speaking patients are not native English speakers. These findings suggest that Japanese MDs need general speaking skills more than discipline-specific expressions and vocabulary and signal the importance of communicative language teachers in English for specific purposes (ESP) education.

https://doi.org/10.37546/JALTJJ42.2-3

JALT Journal, Vol. 42, No. 2, November 2020 
医師にとって英語は大変重要であるが、外国語としての英語に関する医師の二ーズにつ いて検討した研究は少ない。本研究は、西日本の大学病院あるいは一般病院で勤務する医 師を対象に、質問紙およびインタビューにより英語ニーズとして英語使用状況、職務上重 要な英語スキル、学生時代に受けた英語教育に対する意見を調査した。質問紙調査から、 医師は、主に情報収集のために英語を使用しており、学生時代の英語教育ではスピーキン グスキルを伸ばせないと不満を持っていることが示された。インタビューから、即興での 英語使用はストレスであること、例え英語を話す患者であってもその多くがネイティブで ないことが明らかとなつた。以上のことから日本の医師には、領域特有の表現や専門用 語より、一般的スピーキングスキルが必要であり、特定の目的のための英語（English for specific purposes、ESP) 教育に関するコミュニカティブ・ランゲージ教育者の必要性が示 唆された。

Keywords: English for medical purposes; interview; needs analysis; questionnaire

I t has been stressed that Japanese medical doctors (MDs) are in urgent need of improved English skills. Researchers have asserted that poor English proficiency may prevent Japanese MDs from practicing evidence-based medicine (Matsui et al., 2004) and make them less willing to treat foreign patients (Tamamaki \& Nishio, 2013). English teachers involved in English for specific purposes (ESP) instruction may be uniquely placed to help these MDs improve their communication skills, and several in-service English programs for nonnative English-speaking MDs have been described (Hoekje, 2007). However, little has been written about assessing the specific English needs of MDs, whether in Japan or abroad. This paper describes an English needs analysis of MDs conducted in rural Japan for the purpose of informing in-service English programs for MDs.

\section{Needs Analysis}

Needs analysis is a crucial component of ESP instruction (see Dudley-Evans \& St John, 1998). It typically involves a triangulation of quantitative and qualitative data gathered from various stakeholders in a discipline that include domain insiders (disciplinary professionals) and outsiders (e.g., ESP specialists); domain insiders give the assessor an understanding of objective needs, while outsiders elicit subjective needs (Serafini et al., 2015). The type of content upon which the assessor focuses can be defined narrowly, such as specific language tasks, or broadly, such as common-core skills and learning strategies (Belcher, 2006).

In the English for medical purposes (EMP) needs analysis literature, surveys of medical students and faculty shed light on the discrete skills needed 
by these groups. For instance, Taşçi (2011) found that medical students and faculty at a university in Turkey considered reading to be the most important English skill. In Taiwan, Chia et al. (1998) found that medical students considered listening to be the most essential skill; however, medical students surveyed by Hwang and Lin (2010) considered reading to be most important. In Serbia, Antic and Milosavljevic (2016) found speaking to be regarded as a critical English skill.

EMP needs analyses in Japan have also generated diverse findings. For example, Yasunami (2005) found that most medical faculty at one university considered speaking and reading ability to be most essential for MDs, while students perceived EMP skills to be critical to their work. In contrast, Sakata et al. (2015) found that faculty at two Japanese universities tended to favor receptive English skills (reading and listening) over productive skills (speaking and writing), although medical vocabulary was also considered vital. Similarly, medical students surveyed by Noda and Watanabe (2014) considered vocabulary to be important, as well as the need to link EMP courses with medical courses.

However, these needs analyses typically focused on students and faculty rather than clinicians at nonacademic institutions. One problem with relying on data collected from students is that students may be unaware of the skills necessary for their future careers (Liu et al., 2011). On the other hand, university faculty likely have different perceptions regarding Englishlanguage needs from doctors working in nonacademic settings, hence the need to garner information from MDs.

\section{In-Service English Programs}

The English needs of working MDs have been explored less extensively than those of preservice learners and faculty. Hoekje (2007) described in-service English courses for international medical graduates in the United States, although the needs analyses that guided these courses were not described. The need for medical graduates to receive cross-cultural communication skills training has been noted in Australia by Yates et al. (2016), and in Ireland by Maddock and Kelly (2017). However, we are unaware of any published accounts of in-service English programs that have used needs analyses of working MDs and a triangulation of methods and sources (Serafini et al., 2015).

In Japan, Tamamaki and Nishio (2013) found, in a survey of MDs in Kobe, that having had a study abroad experience significantly correlated to a willingness to communicate with foreign patients. Tamamaki and Nishio as- 
serted that Japanese medical schools fail to provide students with adequate English communication skills, forcing students to gain these skills abroad. Thus, educators must seek to create domestic alternatives to study abroad experiences within English education for students in Japan.

We believe that such domestic alternatives can be realized through inservice education programs. Two of the authors of this paper are English teachers, and the other two have healthcare backgrounds in pediatric medicine and pediatric nursing. At the time of this study, we were employed at the same university in western Japan. This needs analysis was narrow in its focus on language skills needed by MDs and involved triangulation of method and location (as recommended by Brown, 2016). We chose to focus on MDs working in the largely rural area of western Japan, as this was the target population for the in-service programs we planned to design.

The research questions guiding this study emerged in discussions among the authors of this paper while developing the research instruments. We first hypothesized that there were differences between the English needs and experiences of MDs working at university hospitals and MDs at hospitals not affiliated with a university. One difference is that involvement in research is obligatory only for MDs at university hospitals. Moreover, MDs at university hospitals may apply for government grants (kakenhi) to fund their research; such funding is unavailable for MDs at other hospitals. MDs at university hospitals may also be involved in education and exchange programs involving international students and faculty. Understanding the differences between these two groups of MDs would help us to plan in-service programs for both groups. Hence, four main questions emerged from our discussions:

RQ1. For what purposes do MDs at (university and nonuniversity) hospitals in western Japan use English for their work?

RQ2. Which English skill (reading, writing, speaking, or listening) do these MDs need most for their work?

RQ3. Which English topics do these MDs regard as most important for future MDs?

RQ4. What do these MDs think about in-service programs for learning English? 


\section{Methodology}

\section{Quantitative Data}

\section{Questionnaire}

A 15-item questionnaire in Japanese was drafted, including a variety of item types. The questionnaire was kept short so as not to be off-putting to busy MDs. The questionnaire was piloted with 21 MDs working at a university hospital. To establish face validity of the questionnaire (see Jungner et al., 2018), two of the authors met with five pilot participants to discuss their responses. The respondents made a few minor suggestions regarding the phrasing and ordering of items. We were also advised to drop two questions concerning frequency of skill use and participants' English education to shorten the questionnaire. Based on this feedback, the questionnaire was revised. The study plan and all materials were then approved by the Institutional Review Board at our university.

\section{Participant Hospitals and MDs}

We then contacted six hospitals and negotiated the method of conducting the survey. In five of the hospitals, paper questionnaires were distributed to all MD staff. The sixth site elected to conduct the survey using their intranet system. Because an electronic survey was used at that site, there was less need to keep it visibly short and thus the two questions excluded from the paper questionnaire following the pilot study were reintroduced. An English translation of the questionnaire used for the sixth site (including all the items) appears in Appendix A. A total of 1,031 questionnaires were distributed and 427 valid responses were received, giving a response rate of $56 \%$. Table 1 shows information about participant hospitals: the number of beds and MDs employed; the number of questionnaires distributed and collected; and response rates.

Responses were then divided into two groups: those from the university hospital (participant hospital 1) and from the five nonuniversity hospitals (participant hospitals 2-6). As the difference between the number of MDs in both groups was not large (186 in the university group, and 241 for the nonuniversity group) we judged that statistical comparisons were appropriate. Completed questionnaires were analyzed using IBM SPSS Statistics (Version 24). Statistical tests consisted of chi-square comparisons and independent samples $t$ tests; effect size was calculated by obtaining Cohen's $d$ and Cramer's $V$, respectively. 
Table 1. Participant Hospitals and Response Rates

\begin{tabular}{|c|c|c|c|c|c|c|}
\hline $\begin{array}{l}\text { त्ञ } \\
\stackrel{0}{0} \\
0 \\
0 \\
0\end{array}$ & 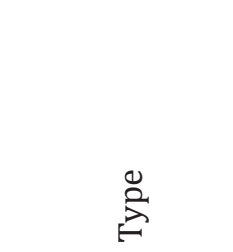 & 告 & $\stackrel{n}{\Sigma}$ & 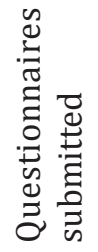 & 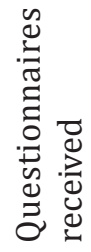 & 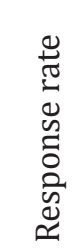 \\
\hline 1 & University & 587 & 213 & 213 & 186 & $87 \%$ \\
\hline 2 & Nonuniversity & 531 & 192 & 192 & 69 & $36 \%$ \\
\hline 3 & Nonuniversity & 482 & 90 & 90 & 56 & $62 \%$ \\
\hline 4 & Nonuniversity & 179 & 32 & 32 & 23 & $72 \%$ \\
\hline 5 & Nonuniversity & 234 & 24 & 24 & 15 & $63 \%$ \\
\hline 6 & Nonuniversity & 1,166 & 480 & 480 & 78 & $16 \%$ \\
\hline
\end{tabular}

General information about respondents (gender, mean number of years of employment, and highest degree earned) is shown in Tables 2 and 3, and the age ranges of MDs are shown in Table 4. We asked participants to select their age range (e.g., 30-39) because we thought some participants might hesitate to write their exact age.

Table 2. Participant Profiles: Gender and Work Experience

\begin{tabular}{|c|c|c|c|c|c|c|c|c|}
\hline \multirow[t]{3}{*}{ Group } & \multicolumn{6}{|c|}{ Gender } & \multirow{2}{*}{\multicolumn{2}{|c|}{$\begin{array}{c}\text { Years } \\
\text { working }\end{array}$}} \\
\hline & \multicolumn{2}{|c|}{ Male } & \multicolumn{2}{|c|}{ Female } & \multicolumn{2}{|c|}{ No response } & & \\
\hline & $n$ & $\%$ & $n$ & $\%$ & $n$ & $\%$ & $M$ & $S D$ \\
\hline $\begin{array}{l}\text { University } \\
(n=186)\end{array}$ & 123 & 68 & 57 & 32 & 6 & 3 & 12.5 & 8.2 \\
\hline $\begin{array}{l}\text { Nonuniversity } \\
(n=241)\end{array}$ & 181 & 77 & 55 & 23 & 5 & 2 & 14.5 & 11.3 \\
\hline
\end{tabular}


Table 3. Participant Profiles: Highest Degree Earned

\begin{tabular}{lccc}
\hline Group & MD & PhD & No response \\
\hline University $(n=186)$ & $120(67)$ & $59(33)$ & $7(4)$ \\
Nonuniversity $(n=241)$ & $180(75)$ & $59(25)$ & $2(1)$ \\
\hline
\end{tabular}

Note. Percentages are presented in parentheses.

Table 4. Participant Profiles: Age Ranges

\begin{tabular}{lccccccc}
\hline Group & 20 & 30 & 40 & 50 & 60 & $70+$ & $\begin{array}{c}\text { No } \\
\text { response }\end{array}$ \\
\hline University & -29 & -39 & -49 & -59 & -69 & & 1 \\
$(n=186)$ & $(10)$ & $(48)$ & $(28)$ & $(10)$ & $(2)$ & $(0)$ & $(0)$ \\
Nonuniversity & 49 & 67 & 56 & 53 & 14 & 1 & 1 \\
$(n=241)$ & $(20)$ & $(28)$ & $(23)$ & $(22)$ & $(6)$ & $(0)$ & $(0)$ \\
\hline
\end{tabular}

Note. Percentages are presented in parentheses.

An independent samples $t$ test was conducted to compare the mean years of work experience between the two groups. A significant difference was found between the university $(M=12.5, S D=8.24)$ and nonuniversity $(M$ $=14.5, S D=11.25)$ groups $(t(410)=-2.11, p=.036 ; d=0.21)$; referring to threshold values described in Kotrlik et al. (2011), the effect size for this analysis was found to be small. The nonuniversity MDs were employed for significantly longer than the university MDs. In addition, chi-square comparisons were made between the two groups for gender, highest degree earned, and age ranges. A significant difference was found for age ranges $\left(\chi^{2}=32.73\right.$, $d f=5, p=.00 ; V=.278)$. The $V$ value (.105) indicated a small, but meaningful, association between the two categories. Although the university group had a higher percentage of MDs in their 30s and 40s, the nonuniversity group consisted of a greater number of MDs below 30 and older than 50; the university group thus included a greater number of mid-career MDs.

\section{Qualitative Data}

Qualitative data included two sources: responses to open-ended items on the questionnaire and semistructured interviews of 10 MDs. A total of 258 MDs wrote responses in Japanese to describe their attitudes towards inservice English programs and their English needs. Interview participants 
were selected through opportunity sampling (Dörnyei, 2007); two MDs who were known to one of the authors were selected, and they recommended other interview candidates. To increase the possibility that participants had experiences using English, they were required to have worked for at least 5 years as MDs. Profiles of interviewees (their gender, department, type of hospital where employed, years of work experience, and experience abroad) are shown in Table 5. One participant (MD1) was exceptional in that she had spent 8 years living abroad (in the United States and Brazil). Five others had no experience residing abroad for over 1 month, and the other four had stayed abroad for less than a year in study-abroad programs at university. Six interviewees were employed at the university hospital where this survey was conducted; the other four were employed at one of the nonuniversity hospitals. Interview questions are included in Appendix B. Informed consent was obtained from all interview participants.

Table 5. Interviewee Profiles

\begin{tabular}{cccccc}
\hline & & & & \\
MD1 & University & Female & Pediatrics & 7 & 8 years \\
MD2 & University & Female & Pediatrics & 15 & None \\
MD3 & University & Male & Pediatrics & 5 & None \\
MD4 & University & Male & Anesthesiology & 15 & 1 month \\
MD5 & University & Female & Hematology & 7 & 6 months \\
MD6 & University & Male & Urology & 12 & None \\
MD7 & Nonuniversity & Male & Urology & 6 & None \\
MD8 & Nonuniversity & Male & Pediatrics & 21 & None \\
MD9 & Nonuniversity & Male & Orthopedic & 10 & 3 months \\
MD10 & Nonuniversity & Male & Gastroenterology & 16 & 11 months \\
\hline
\end{tabular}


Interviews were conducted by one or two of the authors, in either Japanese or English, and were approximately 30 to 90 minutes in length. Interviews were recorded and fully transcribed. Questionnaire responses and interview transcripts underwent thematic coding by the first author using NVivo 11 (QSR International) in consultation with the other authors. The constant comparative method (Boeije, 2002) was used during analysis; themes emerged inductively as sources and the developing coding scheme were compared. To ensure reliability, a randomly selected sample of about $10 \%$ of the data was recoded by a third coder (a Japanese-proficient English teacher), using the prepared coding scheme. Results indicated strong agreement with the first coding ( $\kappa=.85)$, following criteria in Landis and Koch (1977).

\section{Results and Discussion}

\section{Quantitative Findings}

How MDs Use English at Work

The first survey question concerned whether the MDs have used English in their work. These findings are shown in Table 6. A chi-square comparison between the two groups revealed a significant difference $\left(\chi^{2}=4.73, d f=1\right.$, $p=.03$; $V=.105)$. The $V$ value (.105) indicated a weak association between the two categories, meaning MDs at the university hospital used English significantly more than those at the nonuniversity hospitals. However, both groups made use of English at work, and the difference between them (5\%) is not striking.

Table 6. English Use at Work

\begin{tabular}{lcc}
\hline Group & Yes & No \\
\hline University $(n=186)$ & $180(97)$ & $6(3)$ \\
Nonuniversity $(n=241)$ & $221(92)$ & $20(8)$ \\
\hline
\end{tabular}

Note. Percentages are presented in parentheses.

The next question concerned how participants use English at work. Nine options were provided, and more than one item could be selected. These findings are shown in Table 7. The main purpose for using English for both groups was to get information from the Internet or other sources. Chisquare comparisons were done between groups for each item. Significant differences were found for four items: to talk to patients and their families 
$\left(\chi^{2}=6.91, d f=1, p=.009 ; V=.13\right) ;$ to communicate with medical staff $\left(\chi^{2}=\right.$ 8.368, $d f=1, p=.004 ; V=.144)$; to prepare journal manuscripts $\left(\chi^{2}=10.077\right.$, $d f=1, p=.002 ; V=.158)$; and to prepare for international presentations $\left(\chi^{2}=\right.$ $4.724, d f=1, p=.03 ; V=.108$ ). Effect size measurements indicated a weak association between categories, suggesting MDs in the university group were using English significantly less often than the nonuniversity MDs to speak to foreign patients, and significantly more often to communicate with staff, prepare journal manuscripts, and prepare for international presentations.

Table 7. Reasons for Using English at Work

\begin{tabular}{lcc}
\hline Reason & $\begin{array}{c}\text { University } \\
(n=181)\end{array}$ & $\begin{array}{c}\text { Nonuniversity } \\
(n=224)\end{array}$ \\
\hline Domestic presentations & $48(27)$ & $45(20)$ \\
For friends, acquaintances & $33(18)$ & $23(10)$ \\
International presentations & $78(43)$ & $73(33)$ \\
Manuscript preparation & $122(68)$ & $116(52)$ \\
To communicate with staff & $63(35)$ & $49(22)$ \\
To get information & $127(70)$ & $163(73)$ \\
To prepare reports at work & $21(12)$ & $20(9)$ \\
To talk to patients, families & $76(42)$ & $124(55)$ \\
Other & $7(4)$ & $2(1)$ \\
\hline
\end{tabular}

Note. Percentages are presented in parentheses.

The next question asked respondents who had used English at work to choose the English skill (reading, writing, speaking, or listening) most necessary for their work. Table 8 shows these results. MDs in both groups chose reading to be the most necessary skill, followed by speaking, listening, and writing. Chi-square comparisons were made between groups, but no significant differences were found. 
Table 8. The English Skill MDs Need Most

\begin{tabular}{lcc}
\hline Skill & University $(n=176)$ & Nonuniversity $(\mathrm{n}=219)$ \\
\hline Reading & $91(52)$ & $116(53)$ \\
Speaking & $42(24)$ & $54(25)$ \\
Listening & $23(13)$ & $34(16)$ \\
Writing & $20(11)$ & $15(7)$ \\
\hline
\end{tabular}

Note. Percentages are presented in parentheses.

The question concerning how often these MDs were using each skill was included only for the online survey at the sixth hospital site. Reading was the most frequently used skill, with about 70 percent of respondents reading something in English at least once per week. Speaking, listening, and writing occurred less frequently, with most using these skills only a few to several times per year, if at all. These findings are shown in Table 9.

Table 9. Frequency of English Skill Use at One Nonuniversity Hospital

\begin{tabular}{lcccc}
\hline Frequency & $\begin{array}{r}\text { Reading } \\
(n=69)\end{array}$ & $\begin{array}{c}\text { Speaking } \\
(n=68)\end{array}$ & $\begin{array}{c}\text { Listening } \\
(n=68)\end{array}$ & $\begin{array}{c}\text { Writing } \\
(n=67)\end{array}$ \\
\hline Almost every day & $22(32)$ & $0(0)$ & $0(0)$ & $2(3)$ \\
About 2-5 times per week & $15(22)$ & $1(2)$ & $2(3)$ & $2(3)$ \\
About once per week & $11(16)$ & $4(6)$ & $6(9)$ & $8(12)$ \\
About once per month & $9(13)$ & $3(4)$ & $6(9)$ & $11(16)$ \\
About 3-11 times per year & $7(10)$ & $16(24)$ & $20(29)$ & $10(15)$ \\
About 1-2 times per year & $3(4)$ & $32(47)$ & $20(29)$ & $21(31)$ \\
Not using this skill at all & $2(3)$ & $12(18)$ & $14(21)$ & $13(19)$ \\
\hline
\end{tabular}

Note. Percentages are presented in parentheses.

The responses above help to answer the first two research questions posed for this study. First, regarding MDs' purposes for using English, both groups used English mainly to get information, prepare manuscripts, and speak with patients. MDs at the university hospital used English significantly more often than nonuniversity MDs to prepare journal manuscripts, prepare for inter- 
national conference presentations, and communicate with medical staff, but significantly less often to speak to patients. These findings suggest that research activities were indeed of greater concern to the university MDs, while the nonuniversity MDs were more focused on clinical work.

The second research question concerned the skill that participants consider most necessary for their work; both university and nonuniversity MDs considered reading to be most important, with roughly one-third of the MDs at one nonuniversity hospital reading in English almost every day. These findings support several studies (e.g., Taşçi, 2011) that found that MDs or medical students considered reading to be the most important skill for MDs; in fact, the ranking of skills in this study (reading, speaking, listening, and writing) is identical to that in Taşçi (2011).

\section{How MDs Evaluate Their University English Education}

Respondents were asked to indicate the extent to which they agree that the English education they received in university was useful to their work, and of satisfaction to them. Table 10 shows these results. Overall, MDs in both groups viewed their university English education as being neither useful nor satisfactory. Internal reliability estimates for this part of the questionnaire using Cronbach's $\alpha$ showed the reliability of confidence in these items to be .80, which was considered acceptably high (Pallant, 2010). Independent samples $t$ tests found no significant differences between both groups in their responses.

Table 10. How MDs Evaluate Their University English Education

\begin{tabular}{lcccc}
\hline Evaluation & \multicolumn{2}{c}{$\begin{array}{c}\text { University } \\
(n=184)\end{array}$} & \multicolumn{2}{c}{$\begin{array}{c}\text { Nonuniversity } \\
(n=240)\end{array}$} \\
\cline { 2 - 5 } & $M$ & $S D$ & $M$ & $S D$ \\
\hline $\begin{array}{l}\text { University English education useful to } \\
\text { work }\end{array}$ & 2.85 & 1.27 & 2.96 & 1.27 \\
$\begin{array}{l}\text { Satisfied with university English edu- } \\
\text { cation }\end{array}$ & 2.39 & 1.04 & 2.43 & 1.03 \\
\hline
\end{tabular}

Note. 1 = Disagree; 5 = Agree. 


\section{English Topics These MDs Think Medical Students Should Study}

When asked what topics they think medical students should study in their university English education, respondents were given several options; they could select more than one. The most frequently selected topic was speaking (over $80 \%$ for both groups; see Table 11). This was followed by presentation or debate, listening, and reading, though the order of these topics varied by group. These topics were followed, for both groups and in the same order, by writing, EMP, and TOEIC/TOEFL. Surprisingly, EMP was selected by only about 30 percent of respondents in both groups. Chi-square comparisons failed to detect significant differences in any topics between groups.

Table 11. Topics MDs Think Medical Students Should Study

\begin{tabular}{lcc}
\hline Topic & University $(n=181)$ & Nonuniversity $(n=241)$ \\
\hline EMP & $59(32)$ & $75(31)$ \\
Listening & $89(48)$ & $138(57)$ \\
Presentation or debate & $96(52)$ & $121(50)$ \\
Reading & $94(51)$ & $126(52)$ \\
Speaking & $150(81)$ & $198(82)$ \\
TOEIC/TOEFL & $33(18)$ & $39(16)$ \\
Writing & $66(36)$ & $81(34)$ \\
Other & $2(1)$ & $0(0)$ \\
\hline
\end{tabular}

The third research question concerned the English topics both groups believe medical students should study. Both university and nonuniversity MDs considered speaking to be the most important topic for medical students. This finding was somewhat surprising, as respondents had indicated reading to be the most necessary skill for their work. However, speaking is typically the weakest of the four English skills for Japanese learners (Seargeant, 2009); the responses of these MDs may be an acknowledgment of their own weaknesses. Interestingly, both groups of MDs considered EMP to be a lesser need than other topics, a finding reported by Yasunami (2005). The lack of a reported need for standardized exams such as the TOEIC or TOEFL is also apparent. 
Interest in In-service English Training

Last, respondents were asked whether they were interested in participating in programs designed to boost the English skills of medical staff. Over twothirds of respondents were interested (Table 12). A chi-square comparison revealed no significant differences between the two groups. The fourth research question for this study concerned what these MDs think about in-service English learning programs, and these findings indicate that both university and nonuniversity MDs were interested in this topic.

Table 12. MDs' Interest in English In-Service Learning

\begin{tabular}{lccc}
\hline Group & Yes & Maybe & No \\
\hline University $(n=186)$ & $132(71.0)$ & $37(19.9)$ & $17(9.1)$ \\
Nonuniversity $(n=241)$ & $166(68.9)$ & $53(22.0)$ & $22(9.1)$ \\
\hline
\end{tabular}

Note. Percentages are presented in parentheses.

\section{Qualitative Findings}

Interviews and Written Responses from MDs

This section presents findings from an analysis of interviews and openended questionnaire responses. Analysis revealed that several sources of tension between often opposing forces dominated participants' expression of their English needs. These sources of tension were grouped into three categories: English ability, work situation, and perceived roles. How these tensions shaped participants' attitudes towards in-service education formed a fourth category. These categories, and the sources of tension associated with each category, are shown in Figure 1. The following sections will explain how these findings were expressed in the data. All examples in Japanese were translated by the authors of this paper. 


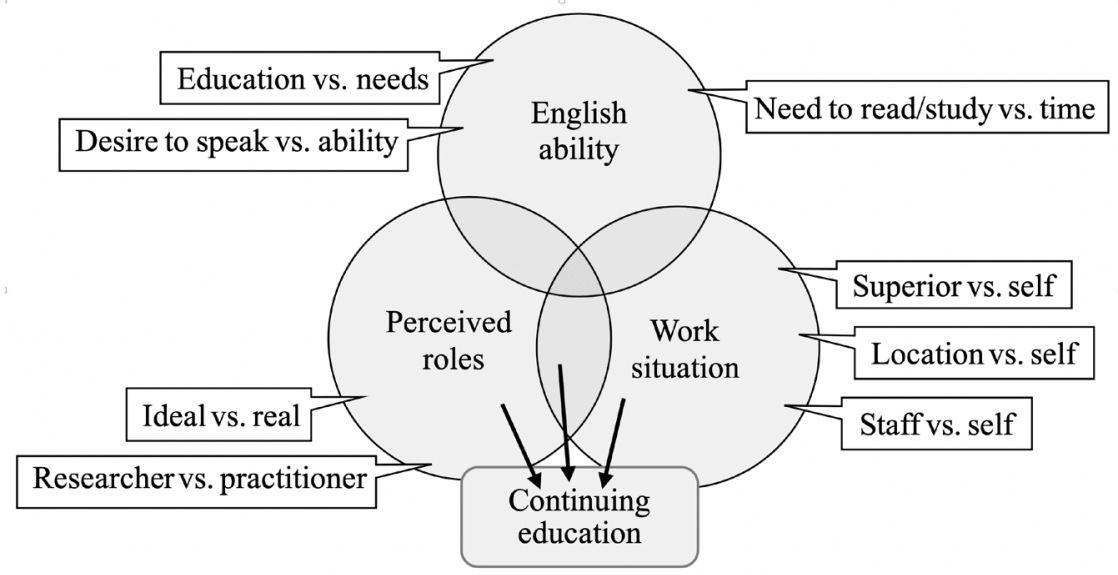

Figure 1. Categories and their main associated tensions from qualitative analysis.

\section{English Ability}

The three sources of tension in this category were (a) education received vs. actual needs, (b) the desire to speak in English vs. actual abilities, and (c) the need to read or study vs. time available.

Criticisms of university English education appeared frequently in written questionnaire responses, as illustrated by the following statement from an MD at the nonuniversity hospital: "In medical education, we don't practice giving presentations or doing debates in English. That's something I want to pursue now" (MD \#210). Interviewees said that their university EMP courses were focused on vocabulary and reading comprehension, which they felt was unnecessary; they were able to pick up vocabulary related to their field through their regular reading as MDs as well as in their medical classes at university.

In questionnaire responses, 25 MDs indicated a desire to speak in English, either with patients or at conferences and other settings, and to improve their speaking skills. The following questionnaire response from a university MD illustrates a common frustration: "I'm having difficulties now when I have to speak in English. And I don't know where to begin to improve my speaking ability" (MD \#70). Several interviewees described communication problems when interviewing foreign patients. For instance, MD8, a pediatrician at the nonuniversity hospital, described an experience in which he was 
unable to communicate with the foreign parent of a child. He wanted to ask questions about the child's symptoms but did not know how to phrase the questions in English. The experience greatly reduced his confidence in his English ability and spurred him to defer responsibility for non-Japanese patients to a colleague; the phenomenon of MDs avoiding foreign patients was noted by Tamamaki and Nishio (2013). The MDs' self-perceived inability to speak well in English may have prevented them from taking on tasks that require English speaking.

Finally, although most considered reading to be their strongest skill, these MDs felt that their English education had failed to prepare them for their work-related reading. Interviewees were reading something in English at least once per week, and often every day, including case reports, research papers, information on websites, and email correspondences. One participant at the university hospital (MD2: a pediatrician) stated that she cannot scan English papers "like native English speakers." She tends to read slowly and painstakingly, translating as she goes, as she had done in high school.

\section{Work Situation}

The three sources of tension in this category were (a) superior vs. self, (b) location vs. self, and (c) staff vs. self.

Most interviewees talked about how a superior in their department encouraged them, explicitly or implicitly, to improve their English; their relationships with these supervisors was often a source of tension. These superiors tended to use English with less hesitation in both formal and informal situations. Their supervisors thus served as role models for the interviewees and could be described as mentors in a mentor-apprentice relationship (Wenger, 1998). For instance, MD9, an orthopedic surgeon at the nonuniversity hospital, believed that his English skills were "better" than those of his department head; however, he noted that his superior was quick to ask questions in English at conferences and his English skills gave him greater confidence in interacting with others.

The location of the hospitals in which they worked also affected their English needs. Several interviewees came from major urban areas, like Tokyo, where they expected an MD's English needs would be different from their current rural setting. MD8, a pediatrician at the nonuniversity hospital, had previously worked in Osaka, where he said there were more Western patients. In his current location, most of the non-Japanese patients he encountered were nonnative English speakers from other Asian countries, such as China or Bangladesh. All interviewees stated that they 
rarely encounter native English-speaking patients in their work. Similar statements were made in the written responses, such as this one from an MD at the nonuniversity hospital: "Recently the number of patients from Asia has increased dramatically. Communicating with them in English or Japanese can be difficult" (MD \#310). This finding meshes with the reality that foreign visitors and residents of Japan are mainly Asian (Japan National Tourism Organization, 2018). Interviewees described how communication with these patients often involved broken English and Japanese, gestures, and writing notes; their speech thus resembled English as a lingua franca communication (Jenkins, 2007).

The tension between staff and self may reveal a difference between how university and nonuniversity MDs use English. Of 13 written responses indicating a need to speak to foreign staff or graduate students in English, 12 responses came from university MDs. Three university interviewees, MD1 (Pediatrics), MD2 (Pediatrics), and MD4 (Hematology), described how they regularly interact with visiting foreign faculty and graduate students in their departments, most of whom come from other Asian countries and cannot speak Japanese. They said that they often have difficulty understanding these people's English accents. These findings may explain the questionnaire result that university MDs used English significantly more often than nonuniversity MDs to communicate with medical staff.

\section{Perceived Roles}

The first source of tension in this category, ideal vs. real, was found chiefly in interview transcripts. Apart from MD1, who had lived several years abroad and was the most comfortable with English, all interviewees made statements that touched upon how they felt they should be able to use English. However, they felt their actual English abilities, coupled with the rigorous demands of their work, held them apart from this ideal.

Reference to the last source of tension in this category, researcher vs. practitioner, appeared in written responses and interviews for both university and nonuniversity MDs. All interviewees at the university hospital, and two of the four at the nonuniversity hospital, were involved in research to varying degrees. For the university interviewees, their roles as researchers and clinical practitioners involved less tension than it did for the nonuniversity MDs due to the available funding and the necessity of research for performance evaluations and promotions. Nonuniversity interviewees, however, often had to use their own money for conferences abroad; moreover, as fewer MDs at their hospitals were involved in research, they felt pressure to 
focus on their work as practitioners. MD8, a pediatrician at the nonuniversity hospital, stated that for those reasons he is "happily retired" from his previous work as a researcher, when his days were "much more stressful."

Regarding their English needs as researchers, interviewees did not feel that they needed support from language teachers for preparing manuscripts, as they were able to receive feedback from mentors and colleagues. Interviewees at the university hospital also had funding to pay for editing and translation services. As mentioned above, however, delivering presentations was more challenging, as was having to use English socially during unscripted moments such as during question and answer sessions and social functions. In her interview, MD2 said that she "dreads" these moments. Discussing research with other people in English can be stressful for Japanese MDs, a problem noted by Guest (2016).

\section{Continuing Education}

Questionnaire written responses and interviews revealed MDs' positive attitudes towards in-service English programs. A focus on speaking skills was considered most attractive, and both medical and nonmedical content would be welcome, provided that speaking was the focus. Interviewees noted that they were not interested in didactic lectures about English, which were sometimes offered as part of faculty-development programs. However, in written responses, 32 MDs stated that they were too busy at work to attend extra English classes. The difficulty medical professionals have in attending in-service programs has been noted by Midorikawa (2016). Seven MDs also wrote that grouping MDs in one course would pose problems. As one MD from the university hospital noted:

I'm strongly interested in participating in such programs, but if we got something like that running at our hospital, some people like me would hesitate to participate. MDs have various English levels and some have an excellent command of English. If I joined such a class I would be embarrassed by my own weak English skills. (MD \#81).

\section{Conclusions}

This study has shown how MDs in one region of Japan use English at work. It was found that these MDs were interested in developing their general English skills, particularly speaking, though the skill they used most for work 
was reading. In addition, when these MDs used English with patients, they were most often speaking to other nonnative English speakers, and the communication techniques they needed may pertain more to English as a lingua franca than English as a native language communication. They felt that their university English education failed to prepare them for their working English needs, which often caused them stress. Large differences were not found between the English needs of MDs at the university hospital and those at nonuniversity hospitals, though university-based MDs were significantly more likely to need English skills for research-related activities. In-service English programs for university-based MDs, therefore, should perhaps have a greater focus on research-related English topics, such as handling question-and-answer sessions at conferences.

Interestingly, participants in this study evaluated EMP instruction in university as significantly less important than speaking skill development; interviewees were able to learn medical vocabulary and expressions in their medical courses as well as in their work. It should be noted that EMP was not defined on the questionnaire, in part because there is no agreed-upon definition of EMP. Although EMP involves all four English skills (Shi, 2009), our impression is that participants equated EMP with vocabulary development, as they stated that their EMP courses were primarily vocabulary- or expression-based. Our findings may thus be heartening to communicative language teachers involved in EMP or ESP instruction because they suggest that the speaking skill development English teachers can provide may matter more than discipline-specific terminology. The specific speaking skills needed by MDs requires clarification, though findings suggest that academic skills such as debate and presentation, as well as communicative or compensatory strategies, would have greater value than traditional English conversation.

In this study, the mentor-apprentice relationship appeared to play a role in how participants viewed English at work. For in-service programs, one intriguing possibility would be to train MDs to become role models to encourage junior MDs to develop their English skills. The role of senior physicians as mentors (or "facilitators") in improving communication skills for caregivers has become integral to training courses at hospitals in North America (Boissy \& Gilligan, 2016). MD mentors in Japan could also become involved in preservice English education, thereby making this education more meaningful to learners.

This study had limitations. Participants may have a false awareness of their own needs, which could have been countered by involving nonpartici- 
pants, such as EMP teachers (Liu et al, 2011). Moreover, the questionnaire was kept short to encourage a high number of responses, sacrificing details on respondents' needs.

\section{Future Directions}

In order to elicit a clearer picture of working MDs' needs, we plan to expand this study to other areas of Japan, and in later surveys we intend to include medical students as participants to gain insights on improving preservice curricula. Applying findings from this study, we have also begun teaching speaking-skills courses for MDs at hospitals in our area. The content has included IELTS-style timed fluency-building tasks, discussion, speech practice, communication strategy instruction and activities taken from the emerging field of "medical improvisation" (see Watson \& Fu, 2016). We hope that future studies and in-service courses help to refine our understanding of EMP and ESP and enable English teachers to teach with greater confidence in the value of their efforts.

\section{Acknowledgments}

We thank the participants for sharing their precious time and insights. We also thank Naomi Fujishima and Carol Rinnert for their feedback on earlier drafts of this paper. This study was supported by a MEXT grant-in-aid for scientific research (\#15K02518).

Ian Willey is an associate professor at Kagawa University. His research interests include teacher identity, English for specific purposes, and second language writing.

Kimie Tanimoto is a pediatric nurse and professor at Kagawa University. She is interested in developing the academic writing skills of nursing researchers.

Gerardine McCrohan is an associate professor at Kagawa University. Her research interests include willingness-to-communicate and communication strategies.

Katsumi Nishiya is a pediatric physician and professor at Kansai Medical University. His research outside of his area of expertise focuses on improving medical education. 


\section{References}

Antic, Z., \& Milosavljevic, N. (2016). Some suggestions for modeling a contemporary medical English course design based on needs analysis. Lingua, 184, 69-78. https://doi.org/10.1016/j.lingua.2016.06.002

Belcher, D. (2006). English for Specific Purposes: Teaching to perceived needs and imagined futures in worlds of work, study, and everyday life. TESOL Quarterly, 40(1), 133-156. https://doi.org/10.2307/40264514

Boeije, H. (2002). A purposeful approach to the constant comparative method in the analysis of qualitative interviews. Quality \& Quantity, 36, 391-409. https://doi. org/10.1023/A:1020909529486

Boissy, A., \& Gilligan, T. (2016). Communication the Cleveland Clinic way. McGraw Hill.

Brown, J. D. (2016). Introducing needs analysis and English for specific purposes. Routledge. https://doi.org/10.4324/9781315671390

Chia, H.-U., Johnson, R., Chia, H.-L., \& Olive, F. (1998). English for college students in Taiwan: A study of perceptions of English needs in a medical context. English for Specific Purposes, 18(2), 107-119. https://doi.org/10.1016/S08894906(97)00052-5

Dörnyei, Z. (2007). Research methods in applied linguistics. Oxford University Press.

Dudley-Evans, T., \& St John, M.-J. (1998). Developments in ESP: A multi-disciplinary approach. Cambridge University Press.

Guest, M. (2016). The underappreciated art of teaching and developing discussion leadership skills. Journal of Medical English Education, 15(3), 119-122.

Hoekje, B. J. (2007). Medical discourse and ESP courses for international medical graduates (IMGs). English for Specific Purposes, 26(3), 327-343. https://doi. org/10.1016/j.esp.2006.09.002

Hwang, Y., \& Lin, S. (2010). A study of medical students' linguistic needs in Taiwan. Asian ESP Journal, 6(1), 35-58.

Japan National Tourism Organization. (2018, February 14). Japan-bound statistics [Data set]. Retrieved January 10, 2019, from https://www.tourism.jp/en/ tourism-database/stats/inbound/\#annual

Jenkins, J. (2007). English as a lingua franca: Attitude and identity. Oxford University Press.

Jungner, J. G., Tiselius, E., Wenemark, M., Blomgren, K., Lützén, K., \& Pergert, P. (2018). Development and evaluation of the Communication over Language Barriers questionnaire (CoLB-q) in paediatric healthcare. Patient Education and Counseling, 101(9), 1661-1668. https://doi.org/10.1016/j.pec.2018.04.007 
Kotrlik, J., Williams, H., \& Jabor, K. (2011). Reporting and interpreting effect size in agricultural education research. Journal of Agricultural Education, 52(1), 132-142.

Landis, J. R., \& Koch, G. G. (1977). The measurement of observer agreement for categorical data. Biometrics, 33(1), 159-174. http://dx.doi.org/10.2307/2529310

Liu, J.-Y., Chang, Y.-J., Yang, F.-Y., \& Sun, Y.-C. (2011). Is what I need what I want? Reconceptualising college students' needs in English courses for general and specific/academic purposes. Journal of English for Academic Purposes, 10(4), 271-280. https://doi.org/10.1016/j.jeap.2011.09.002

Maddock, C., \& Kelly, F. (2017). Doctor-patient communication issues for international medical graduates and medical graduates of foreign origin in Ireland. European Psychiatry, 41(S1), s897-s898. https://doi.org/10.1016/j. eurpsy.2017.01.1831

Matsui, K., Ban, N., Fukuhara, S., Shimbo, T., Koyama, H., Nakamura, S., Nago, N., Fukuoka, T., \& Fukui, T. (2004). Poor English skills as a barrier for Japanese health care professionals in learning and practising evidence-based medicine. Medical Education, 38(11), 1203-1205. https://doi.org/10.1111/j.13652929.2004.01973.x

Midorikawa, M. (2016). Efforts to improve the English skills of doctors at Aso Iizuka Hospital. Journal of Medical English Education, 15(3), 150-151.

Noda, C., \& Watanabe, A. (2014). 医学英語カリキュラムの今後の可能性と課題 [Future directions for curriculum development in English for medical purposes]. Journal of Medical English Education, 13(3), 65-74.

Pallant, J. (2010). SPSS survival manual (4th ed.). Open University Press.

Sakata, N., Tanaka, E., Fujieda, M., Suzuki, K., \& Nakamura,Y. (2015). Can-do statementsを利用した医学英語教育ニーズの分析 [Assessing English needs of medical students using can-do statements]. Journal of Medical English Education, 14(1), 15-24.

Seargeant, P. (2009). The idea of English in Japan: Ideology and the evolution of a global language. Multilingual Matters. https://doi. org/10.21832/9781847692030

Serafini, E. J., Lake, J. B., \& Long, M. H. (2015). Needs analysis for specialized learner populations: Essential methodological improvements. English for Specific Purposes, 40, 11-26. https://doi.org/10.1016/j.esp.2015.05.002

Shi, L. (2009). English for medical purposes. In D. Belcher (Ed.), English for Specific Purposes in Theory and Practice (pp. 205-228). The University of Michigan Press.

Taşçi, C. (2011). An analysis of medical students' English language needs: A needs analysis for curriculum development. Lambert Academic Publishing. 
Tamamaki, K., \& Nishio, K. (2013). 外国人患者に対する医療を促進するために日本の医 学教育は何を提供できるだろうか [How can Japanese medical education promote medicine to foreign patients?]. Journal of Medical English Education, 12(2), 27.

Watson, K., \& Fu, B. (2016). Medical improv: A novel approach to teaching communication and professionalism skills. Annals of Internal Medicine, 165(8), 591-592. https://doi.org/10.7326/M15-2239

Wenger, E. (1998). Communities of practice: Learning, meaning, and identity. Cambridge University Press.

Yasunami, S. (2005). 医学英語教育のためのニーズ分析 [Needs analysis for EMP]. Bulletin of the JACET Kysuhu-Okinawa Chapter ESP SIG, 4, 91-99.

Yates, L., Dahm, L. R., Rogers, P., \& Cartmill, J. (2016). Developing rapport in inter-professional communication: Insights for international medical graduates. English for Specific Purposes, 42, 104-116.

\section{Appendix A.}

\section{Questionnaire (English Translation)}

Please answer the Background Questions below before answering the Survey Questions.

\section{Background Questions}

1. Job title (Please fill in):

2. Gender (Please circle): $\mathrm{M} / \mathrm{F}$

3. Age range (Please circle): 20-29 30-39 40-49 50-59 60-69 70+

4. Number of years as a medical doctor: years (and/or) months

5. Highest degree earned (Please fill in):

\section{Survey Questions}

6. Have you ever used English in your work as a medical doctor? (Circle one) YES NO If YES, please answer questions 7-9. If NO, please proceed to question 10.

7. For what purposes have you used English? (You may circle more than one answer)

a. To communicate with patients or their family members

b. To communicate with other healthcare professionals in your place of work 
c. To read articles or other healthcare information in journals or online, etc.

d. To write work-related reports

e. To write papers for submission to journals

f. To present at local or regional conferences

g. To present at international conferences (in Japan or abroad)

h. To communicate with colleagues, acquaintances, or friends

i. Other purposes (please fill in):

8. Which English skill do you feel is most important for your work? (Circle one)
a. Reading
b. Speaking
c. Listening
d. Writing

9. How often do you use the following English skills? (Circle one response per skill)
(A) Reading
(B) Speaking
1. Almost every day
1. Almost every day
2. 2-5 times per week
2. 2-5 times per week
3. Once per week
3. Once per week
4. Once per month
4. Once per month
5. 3-11 times per year
5. 3-11 times per year
6. 1-2 times per year
6. 1-2 times per year
7. Not using at all
7. Not using at all

(C) Listening

(D) Writing

1. Almost every day

1. Almost every day

2. 2-5 times per week

2. 2-5 times per week

3. Once per week

3. Once per week

4. Once per month

4. Once per month

5. 3-11 times per year

5. 3-11 times per year

6. 1-2 times per year

6. 1-2 times per year

7. Not using at all

7. Not using at all

(Everyone should respond to the remaining questions)

10. To what extent do you agree or disagree with the following statements? (Circle one answer for each statement)

(A) English classes in university helped to prepare me for my work as a medical doctor.
a. Agree
b. Somewhat agree
c. Neutral
d. Somewhat disagree
e. Disagree 
(B) I am satisfied with the English education I received in university.
a. Agree
b. Somewhat agree
c. Neutral
d. Somewhat disagree
e. Disagree

(C) Using English gives me stress.
a. Agree
b. Somewhat agree
c. Neutral
d. Somewhat disagree
e. Disagree

(D) English is necessary for medical doctors.
a. Agree
b. Somewhat agree
c. Neutral
d. Somewhat disagree
e. Disagree

11. Which English skills/activities do you think are most important in English education for medical students?* (You may circle more than one of the below)
a. TOEIC/TOEFL or other exam preparation
b. Speaking
c. Reading
d. Writing
e. Listening
f. Presentation or debate
g. Medical or nursing English
h. Other: (please fill in)

12. Which level of English education do you think was most beneficial to your English needs as a medical doctor?* (Circle one)
a. Junior High School
b. High School
c. English conversation school, etc.
d. College or university
e. Other (Explain:

13. Would you be interested in programs or courses that center on boosting the English skills of medical staff? (Circle one)

YES MAYBE NO

14. Please write your reason for your response to Question 15, as well as any thoughts you may have about such English skill-development programs or courses.

15. Please write freely about your present English needs.

*Items included only in questionnaires distributed at the sixth site (a nonuniversity hospital) 


\section{Appendix B.}

\section{Interview Protocol (English Translation)}

\section{English Education (Background Questions)}

1. How many years have you studied English in total?

2. Describe your previous English learning experiences, from the earliest to the latest.

3. Please describe your English education experience at university.

4. Which period of English education do you feel was most useful for your present work?

5. Which period of English education do you feel was least useful for your present work?

6. Overall, do you feel satisfied with your previous English education? Explain.

7. How do you feel your previous English education could have been improved?

8. Have you experienced living or studying abroad for one month or more? If yes, where?

9. Are you currently studying English in any way?

\section{Interviewee's Overall English Skill Level and Current Usage at Work}

10. If you could evaluate your overall English ability on a range from 1 to 10 , what score would you give yourself? Explain why you would give yourself this score.

11. What do you feel is your strongest skill in English, among the four skills of listening, reading, speaking, and writing?

12. What do you feel is your weakest skill in English among these four skills?

13. How often would you say you are using each of the four skills?

14. For what purposes are you using each skill?

15. What do you read most frequently in English? For what purposes?

16. Are you using English to communicate with foreign patients? Foreign staff? How frequently? Please describe these experiences.

\section{Thoughts About English Skill Development Programs or Courses}

17. Are you interested in any kind of English skill-up programs or courses? Why or why not? 
18. If you are interested, what sort of topics would you be interested in studying?

19. Are there any obstacles to your participation in such programs or courses?

20. What times/formats would be easiest for you to participate?

21. Have you ever experienced any such programs or courses for medical doctors before? If so, please describe these experiences. Did you find them useful?

22. Who do you feel should teach such courses?

23. Do you have anything else you'd like to say about English skill-development programs?

24. Do you have anything else you'd like to say about the subject of English at work? 